\title{
The influence of upstream weir slope on live-bed scour at submerged weir
}

\author{
L. Wang, B.W. Melville \& H. Friedrich \\ Department of Civil and Environmental Engineering, University of Auckland, New Zealand
}

\begin{abstract}
Shape variation of submerged weirs can change local flow patterns and sediment transport. The aim of this study is to quantify and compare the local scour at weirs with different upstream face slopes, under submerged flow and live-bed conditions. Experiments were carried out on $30 \mathrm{~mm}$ high weirs in a tilting, sediment recirculating flume with $0.26 \mathrm{~mm}$ uniform sediment. 24 experiments were undertaken involving four different upstream weir face angles $\left(30^{\circ}, 45^{\circ}, 60^{\circ}\right.$ and $90^{\circ}$ to the horizontal) and six flow intensities. Two webcams were employed to observe upstream aggradation and the local scour on both sides of the weir. The results indicate that a gentler upstream weir slope reduces the upstream scour depth at the submerged weir, for upstream weir face angle greater than $45^{\circ}$. The results also show that the downstream scour depth is independent of the upstream weir slope.
\end{abstract}

\section{INTRODUCTION}

Weir-like structures that span the width of the channel (e.g. bed sills, groynes, check dams, submerged weirs) are frequently installed in rivers to control water level and stabilize the bed from excessive degradation (Guan et al., 2015). Flow over such structures has a potential to cause considerable scour, possibly leading to damage or failure. The flow over weirs can be classified into free flow and submerged flow. Hager and Schwalt (1994) defined submerged flow as beginning when the upstream water level starts to increase with increasing tailwater depth, the flow is defined as submerged flow. Although somewhat arbitrary, this definition has been found to be helpful (Hager and Schwalt, 1994, Fritz and Hager, 1998, Schmocker et al., 2011).

Up to the present, many studies have investigated scouring downstream of a weir-like structure (Ben Meftah and Mossa, 2006, Bormann and Julien, 1991, D'Agostino and Ferro, 2004, Gaudio et al., 2000, Lenzi et al., 2002, Lenzi et al., 2003a, Lenzi et al., 2003b, Lu et al., 2012, Marion et al., 2006, Marion et al., 2004, Pagliara and Kurdistani, 2013, Scurlock et al., 2011). However, very few of these studies included the effects of sediment supply or considered the situation of submerged flow (Guan, 2015).

Guan (2015) reviewed the existing empirical equations for local scour at weir-like structures, and systematically studied local scour and its flow pattern at vertical faced submerged weirs in a tilting sediment-recirculating laboratory flume. Based on an analysis of their experimental data, they proposed a series of dimensionless equations to predict the upstream scour depth for live-bed scour conditions (Eq. 1), and the downstream scour depth for both live-bed scour conditions (Eq. 2) and clear-water scour conditions (Eq.3). All of these equations include the effects of sediment size, tailwater depth and weir height.

$$
\begin{aligned}
& \frac{d_{u s \_a}}{h_{t}}=3.40\left(\frac{z}{h_{t}}\right)^{-0.13}\left(\frac{d_{50}}{h_{t}}\right)^{0.52}\left(\frac{U_{0}}{U_{c}}-0.65\right)\left(3.90-\frac{U_{0}}{U_{c}}\right) \\
& 1<U_{0} / U_{c} \leq 3.65 \\
& \frac{d_{s \_a}}{h_{t}}=4.50\left(\frac{z}{h_{t}}\right)^{1.10}\left(\frac{d_{50}}{h_{t}}\right)^{0.07}\left[\left(\frac{U_{0}}{U_{c}}-0.90\right)+\frac{0.23}{\left(\frac{U_{0}}{U_{c}}-0.90\right)}\right] \\
& 1<U_{0} / U_{c} \leq 3.65
\end{aligned}
$$

$\frac{d_{s_{-} a}}{h_{t}}=17.42\left(\frac{z}{h_{t}}\right)^{1.10}\left(\frac{d_{50}}{h_{t}}\right)^{0.07}\left(\frac{U_{0}}{U_{c}}-0.4\right)$

$0.4<U_{0} / U_{c} \leq 1$

In these equations, $d_{u s ~} a$ is the average upstream scour depth, $d_{s_{-} a}$ is the average downstream scour depth, $h_{t}$ is the tailwater depth, $d_{50}$ is the median diameter of sand, $z$ is weir height, where $d_{u s_{-} a}, d_{s_{-} a}, h_{t}$, 
$h_{a}, h_{0}$ and $z$ are referenced to the initial flat bed (Fig. 1). $U_{0}$ is the average velocity of approach flow, for the cross-section above the equilibrium bed level (i.e. where the flow depth is equal to $h_{0}$ ). $U_{c}$ is the average critical approach velocity for initiation of sand movement; it is calculated by the logarithmic velocity profile function $U_{c} / u_{*_{c}}=5.75 \log \left(5.53 h_{0} / d_{50}\right)$. However, the experiments of Guan (2015) were limited to rectangular weirs with a narrow rectangular cross-section shape. The effects of weir shape could change the sediment transport and flow pattern around the submerged weir, and these effects should be considered for design. In this paper, 24 experiments were conducted in a sediment recirculating flume, using weirs with different upstream face angles to explore the upstream face angle effects on the local scour at a submerged weir under live-bed scour conditions.

\section{EXPERIMENTS}

\subsection{Experimental set-up}

The experiments were conducted in a $12 \mathrm{~m}$ long, $0.38 \mathrm{~m}$ deep and $0.44 \mathrm{~m}$ wide tilting sandrecirculating flume with glass side-walls, in the Hydraulics Laboratory of The University of Auckland. The recirculating system consists of a pump and a sand pump. The sand pump rate was set at a constant value that is sufficient to recirculate the sediment. The water pump rate is adjusted by an electronic controller. Both water and sand are pumped to a mixing chamber located at the upstream inlet of the flume, and enter the open channel via a honey-comb flow straightener. At the flume outlet, bed-load sediment is deposited in a hopper-like sump and recirculated to the inlet through the sand pump. The flume slope is adjusted using a jack incorporated in the flume. Four weirs, each of $30 \mathrm{~mm}$ height with different upstream face angle $\left(30^{\circ}, 45,60^{\circ}\right.$ and $90^{\circ}$ to the horizontal) were employed. The submerged weirs each had a $10 \mathrm{~mm}$ wide crest and were of the same width as the flume. A uniform fine sand with $d_{50}=0.26 \mathrm{~mm}$ was used. The characteristics of the bed material are presented in Table 1. The critical shear velocity, $u_{*_{\mathrm{c}}}$, is determined from the Shields curve for different grain sizes (Melville, 1997).

Table 1. Grading distribution of sand used as bed material

\begin{tabular}{llllllll}
\hline $\begin{array}{l}d_{16} \\
(\mathrm{~mm})\end{array}$ & $\begin{array}{l}d_{30} \\
(\mathrm{~mm})\end{array}$ & $\begin{array}{l}d_{50} \\
(\mathrm{~mm})\end{array}$ & $\begin{array}{l}d_{84} \\
(\mathrm{~mm})\end{array}$ & $\begin{array}{l}d_{90} \\
(\mathrm{~mm})\end{array}$ & $\begin{array}{l}\sigma_{g} \\
(-)\end{array}$ & $\begin{array}{l}\Delta \\
(-)\end{array}$ & $\begin{array}{l}u_{*_{c}} \\
(\mathrm{~m} / \mathrm{s})\end{array}$ \\
\hline 0.16 & 0.22 & 0.26 & 0.36 & 0.43 & 1.5 & 1.65 & 0.013 \\
\hline
\end{tabular}

* $\sigma_{g}$ is the standard deviation of sediment size; $\Delta$ is the relative submerged particle density.
All the experiments were conducted under livebed scour conditions. The hydraulic conditions and the experimental results are presented in Table 2.

\subsection{Bed profile measurements}

A Logitech HD webcam was placed on each side of the flume to record the scouring process. Both webcams were at the same distance along the flume and at the same height. Scour depths were measured with the assistance of transparent grid sheets placed on the glass walls. The locations of the webcams and the distance between the webcams and the flume glass walls were adjusted to enable the webcam's diagonal field of view $\left(78^{\circ}\right)$ to cover the scour hole. The scour profiles were obtained from successive pictures taken with a constant frequency in each test. The described depth measurements technique has an accuracy of $\pm 2 \mathrm{~mm}$.

Although the flow and weir were twodimensional, the upstream and downstream scour holes at the weir were observed to be threedimensional, on account of the migrating threedimensional ripples and the unsteady secondary flows generated in the scour holes themselves. Thus, the scour depth at any particular time was not constant across a cross section; sometimes the maximum scour depth was more than two times the minimum. The maximum scour depth was observed to be very near the side walls of flume most of the time in each live-bed scour test. Accordingly, the maximum scour depths on the side walls are considered to be the scour depths of the scour holes around the submerged weir. Scour depths upstream $\left(d_{u s}\right)$ and downstream $\left(d_{s}\right)$ of the weir were extracted at constant time intervals throughout each test. The timeaveraged value of $d_{u s}$ and $d_{s}$ after reaching the equilibrium condition defined in Guan et al. (2014) were considered to be the equilibrium average scour depths $\left(d_{u s a}\right.$ and $\left.d_{s_{a} a}\right)$. The maximum scour depths during the test $\left(d_{u s_{-} \max }\right.$ and $\left.d_{s_{-} \max }\right)$ and the aggradation height $\left(h_{a}\right)$ were also recorded. The definitions of all measurements above follow Guan et al. (2015).

For the tests of each weir type, the bed was flattened initially. An experiment under higher flow-rate $(Q)$ was started continuously after the finish of a lower flow-rate test. The same method was used by Sheppard and Miller (2006). The channel slope was adjusted to obtain a constant tailwater depth $\left(h_{t}\right)$ of $150 \mathrm{~mm}$. The water level difference between upstream and downstream of the weir in the equilibrium stage, $H_{d}$ was measured with a point gage. The average approach flow depth, $h_{0}$, is calculated as $h_{0}$ $=h_{t}+H_{d}-h_{a}$. A sketch of the measurements described above is shown in Figure 1. The upstream Froude number, $F_{r}$, is between 0.26 and 0.79 . 


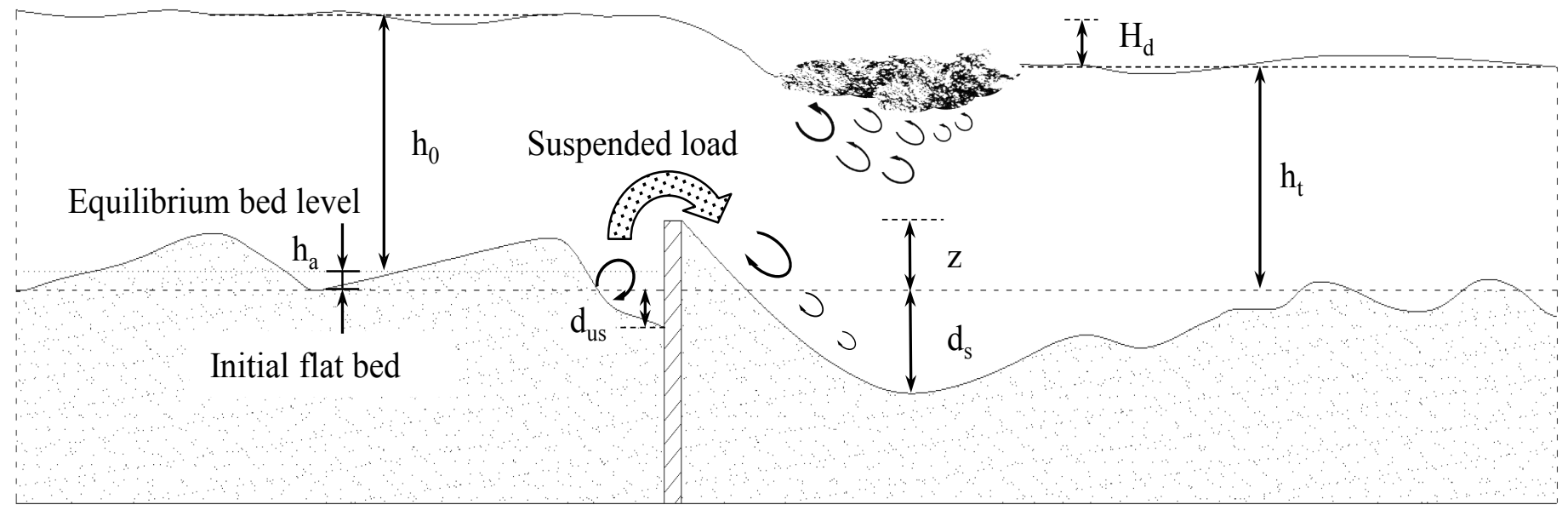

Figure 1. Definition sketch of live-bed scour at a submerged weir, after Guan et al. (2015)

Table 2. Summary of experimental conditions and results

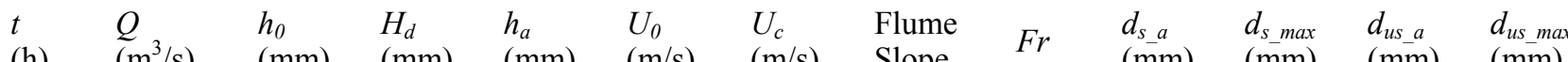

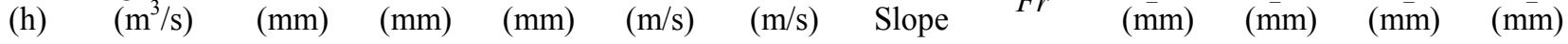

\begin{tabular}{|c|c|c|c|c|c|c|c|c|c|c|c|c|c|}
\hline \multirow{6}{*}{$a=90^{\circ}$} & 50.4 & 0.0218 & 154 & 1 & -3 & 0.322 & 0.271 & 0.0009 & 0.27 & 60 & 67 & 34 & 61 \\
\hline & 23.9 & 0.0308 & 149 & 3 & 4 & 0.470 & 0.270 & 0.0014 & 0.39 & 85 & 100 & 45 & 73 \\
\hline & 12.5 & 0.0395 & 151 & 6 & 5 & 0.595 & 0.270 & 0.0020 & 0.49 & 117 & 128 & 56 & 122 \\
\hline & 6.0 & 0.0481 & 149 & 9 & 10 & 0.734 & 0.270 & 0.0027 & 0.60 & 126 & 143 & 43 & 116 \\
\hline & 2.9 & 0.0532 & 151 & 10 & 9 & 0.801 & 0.270 & 0.0033 & 0.67 & 132 & 147 & 0 & 0 \\
\hline & 2.7 & 0.0615 & 150 & 10 & 10 & 0.932 & 0.270 & 0.0033 & 0.79 & 145 & 152 & 0 & 0 \\
\hline \multirow{6}{*}{$a=60^{\circ}$} & 71.1 & 0.0218 & 155 & 1 & -4 & 0.320 & 0.271 & 0.0009 & 0.26 & 42 & 50 & 26 & 52 \\
\hline & 22.4 & 0.0308 & 153 & 3 & 0 & 0.458 & 0.271 & 0.0014 & 0.38 & 87 & 95 & 32 & 61 \\
\hline & 8.4 & 0.0395 & 154 & 6 & 2 & 0.583 & 0.271 & 0.0020 & 0.48 & 108 & 125 & 39 & 72 \\
\hline & 10.4 & 0.0481 & 153 & 9 & 6 & 0.714 & 0.271 & 0.0027 & 0.59 & 115 & 126 & 20 & 40 \\
\hline & 4.3 & 0.0532 & 152 & 9 & 7 & 0.803 & 0.270 & 0.0033 & 0.65 & 123 & 130 & 0 & 0 \\
\hline & 3.4 & 0.0615 & 152 & 10 & 8 & 0.943 & 0.270 & 0.0033 & 0.76 & 153 & 160 & 0 & 0 \\
\hline \multirow{6}{*}{$a=45^{\circ}$} & 52.1 & 0.0218 & 157 & 1 & -6 & 0.316 & 0.271 & 0.0009 & 0.26 & 50 & 60 & 17 & 33 \\
\hline & 24.0 & 0.0308 & 157 & 3 & -4 & 0.446 & 0.271 & 0.0014 & 0.37 & 74 & 88 & 21 & 43 \\
\hline & 12.2 & 0.0395 & 155 & 6 & 1 & 0.579 & 0.271 & 0.0020 & 0.48 & 104 & 120 & 24 & 53 \\
\hline & 5.6 & 0.0481 & 154 & 9 & 5 & 0.710 & 0.271 & 0.0027 & 0.59 & 115 & 130 & 11 & 26 \\
\hline & 3.3 & 0.0532 & 152 & 9 & 7 & 0.803 & 0.270 & 0.0033 & 0.65 & 120 & 130 & 0 & 0 \\
\hline & 3.0 & 0.0615 & 152 & 9 & 7 & 0.943 & 0.270 & 0.0033 & 0.75 & 148 & 155 & 0 & 0 \\
\hline \multirow{6}{*}{$\mathrm{a}=30^{\circ}$} & 50.6 & 0.0218 & 159 & 1 & -8 & 0.312 & 0.272 & 0.0009 & 0.26 & 34 & 40 & 16 & 27 \\
\hline & 23.2 & 0.0308 & 157 & 3 & -4 & 0.446 & 0.271 & 0.0014 & 0.37 & 73 & 85 & 22 & 37 \\
\hline & 11.3 & 0.0395 & 158 & 6 & -2 & 0.568 & 0.272 & 0.0020 & 0.47 & 109 & 124 & 25 & 50 \\
\hline & 6.5 & 0.0481 & 152 & 9 & 7 & 0.719 & 0.270 & 0.0027 & 0.59 & 126 & 140 & 15 & 31 \\
\hline & 3.4 & 0.0532 & 152 & 10 & 8 & 0.803 & 0.270 & 0.0033 & 0.66 & 129 & 140 & 0 & 0 \\
\hline & 3.0 & 0.0615 & 153 & 10 & 7 & 0.937 & 0.271 & 0.0033 & 0.75 & 146 & 152 & 0 & 0 \\
\hline
\end{tabular}



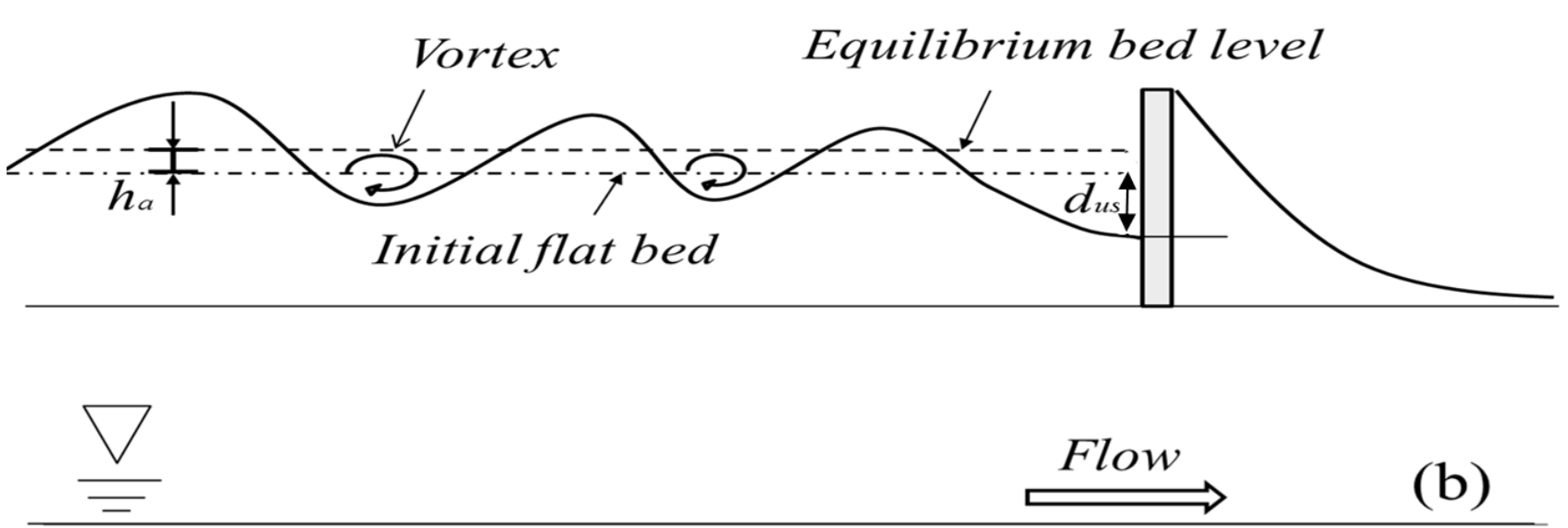

Flow

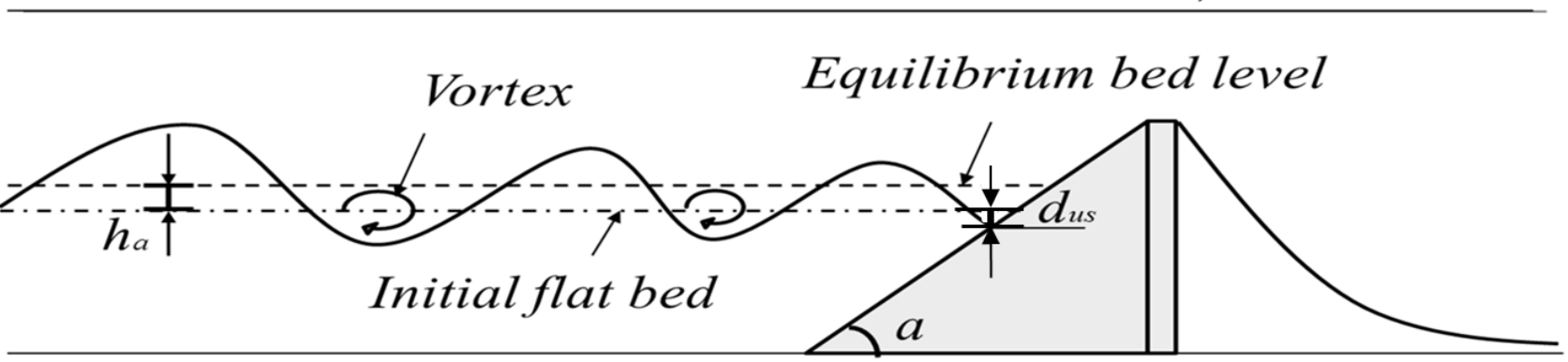

Figure 3. Generalized model of scouring at rectangular weir (a) and weir with upstream slope (b)

\section{RESULT AND DISCUSSION}

Flow intensities $\left(U_{o} / U_{c}\right)$ in the experiments were between 1.2 and 3.5. The dimensionless mean upstream and downstream scour depth $\left(d_{u s \_a} / h_{t}\right.$ and $\left.d_{s} a / h_{t}\right)$ of each weir type are plotted in Figure 2 and Figure 4, respectively, for different flow intensities.

Figure 2 shows that the averaged upstream scour depth plotted against the normalized velocity has the same trend for each weir type. The trend is increasing when $U_{o} / U_{c}$ is between 1.2 and about 2.2, then decreases to zero as $U_{o} / U_{c}$ increases to about 3 . For $U_{o} / U_{c}$ between 3.0 to 3.4 (maximum intensity in this study), the upstream bedform becomes planebed (transition). It can be seen that the upstream scour depth reduces as the upstream weir face angle decreases. For $a>45^{\circ}$, the scour depth does not appear to change with $a$. The black triangular symbol in Figure 2 represents the value $\eta_{c} / 2-h_{a}$, where $\eta_{c}$ is the estimated bedform height using the Van Rijn (1984) predictor. A generalized model is sketched in Figure 3 to help explain the underlying mechanism. During the experiments it was observed that a vortex is generated in the trough of the bedform. When the bed-form trough is approaching the weir, the vortex is squeezed by the weir face because of the deformation of the trough shape. As a consequence, the flow intensity in the vortex is increased, more sediment is removed from the trough, and the scour hole becomes deeper. The size of upstream scour hole is therefore determined by the bedform height (which depends on the flow intensity); this is the reason why the normalized upstream scour depth has the same trend for all upstream weir face angles, and it is also the reason that the upstream scour depth becomes zero when the upstream bed form is transition flat. As the upstream weir face angle decreases, deformation of the vortex reduces, and the amount of sediment removed becomes less than that for a rectangular weir. When the weir face angle becomes less than $45^{\circ}$, the enhanced flow intensity of the squeezed vortex is inadequate to transport more sediment from the trough. In this situation, the upstream scour depth reaches its lower limit, which is equal to $\eta_{c} / 2-h_{a}$. 


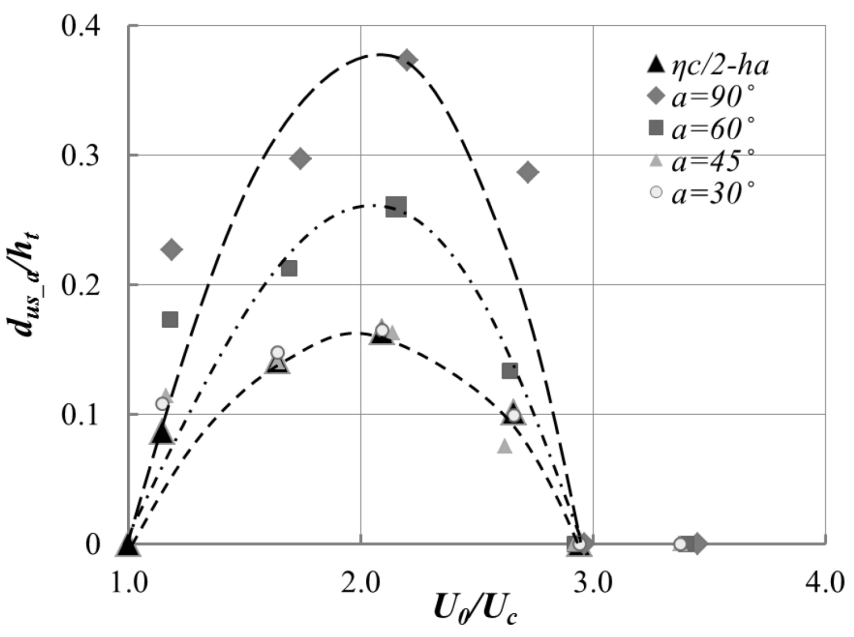

Figure 2. Normalized average upstream scour depth vs. flow intensity

Figure 4 shows that the averaged downstream scour depths of all weir types are approximately the same at each experimental intensity, which indicates that the downstream scour depth is independent of upstream face angle under live-bed scour conditions. The normalized downstream scour depth increases as the velocity increases, but the rate of increase is less for $U_{o} / U_{c}$ between about 2.0 to 3.0. This is reasonable because, for a particular flow intensity, the water level difference, $H_{d}$ (Table 2 ) is almost constant for varied weir slope. Because the downstream weir shape and the upstream sediment load are not changed, the flow pattern over the weir is unchanged and maintains the downstream scour hole depth of a rectangular weir.

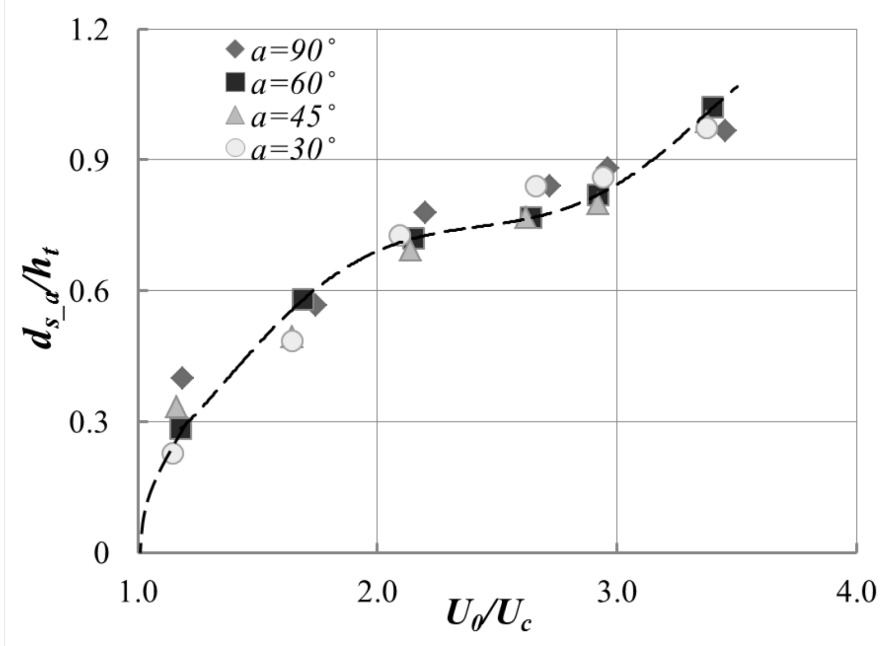

Figure 4. Normalized average downstream scour depth vs. flow intensity

\section{CONCLUSION}

The effects of upstream weir face angle on local scour at a submerged weir were studied in a sediment recirculating flume under live-bed scour conditions using four types of weir (upstream weir face angle $30^{\circ}, 45^{\circ}, 60^{\circ}$ and $90^{\circ}$ to the horizontal). It is found that a gentler upstream weir face angle can reduce upstream scour depth. This reduction is because of the underlying mechanism in the interaction between the bedform trough vortex and the weir face; the reduction increases with increasing weir face angle for angles up to $45^{\circ}$, at which angle the upstream scour depth reaches its lower limit of calculated half bedform height minus upstream aggradation height. The experimental results also show that the downstream scour depth is independent of the upstream slope of weir.

\section{ACKNOWLEDGEMENT}

The authors would like to acknowledge the valuable suggestions from Dr. Keith Adams. Also, the first author would like to thank the China Scholarship Council for the financial support.

\section{NOTATION}

The following symbols are used in this paper:

$B=$ channel width $(\mathrm{m})$

$b=$ weir width $(\mathrm{m})$

$d_{x}=$ sediment size, for which $\mathrm{x} \%$ (in weight) of sediment particles are finer $(\mathrm{mm})$

$d_{u s}=$ scour depth upstream of the weir in each measurement ( $\mathrm{mm})$

$d_{u s_{-} a}=$ equilibrium scour depth upstream of the weir $(\mathrm{mm})$

$d_{u s_{-} \max }=$ maximum scour depth upstream of the weir (mm)

$d_{s}=$ scour depth downstream of the weir in each measurement (mm)

$d_{s_{-} a}=$ equilibrium scour depth downstream of the weir $(\mathrm{mm})$

$d_{s_{-} \max }=$ maximum scour depth downstream of the weir $(\mathrm{mm})$

$F_{r}=$ Froude number upstream of the weir (-)

$g=$ acceleration of gravity $\left(\mathrm{ms}^{-2}\right)$

$H_{d}=$ water level difference across the weir (mm)

$h_{0}=$ average approach flow depth (mm)

$h_{a}=$ aggradation height $(\mathrm{mm})$ 
$h_{t}=$ tailwater depth $(\mathrm{mm})$

$\mathrm{Q}=$ flowrate $\left(\mathrm{m}^{3} \mathrm{~s}^{-1}\right)$

$t=$ scour time (h)

$U_{0}=$ average approach flow velocity $\left(\mathrm{ms}^{-1}\right)$

$U_{c}=$ critical average approach flow velocity $\left(\mathrm{ms}^{-1}\right)$

$u_{*_{c}}=$ critical shear velocity $\left(\mathrm{ms}^{-1}\right)$

$z=$ weir height $(\mathrm{mm})$

$a=$ upstream weir face angle

$\Delta=$ relative submerged particle density $(-)$

$\eta_{c}=$ calculated bedform heights $(\mathrm{mm})$

$v=$ kinematic viscosity of fluid $\left(\mathrm{m}^{2} \mathrm{~s}^{-1}\right)$

$\sigma_{g}=$ standard deviation of sediment size (-)

\section{REFERENCES}

BEN MEFTAH, M. \& MOSSA, M. (2006) Scour holes downstream of bed sills in low-gradient channels. Journal of Hydraulic Research, 44, 497-509.

BORMANN, N. E. \& JULIEN, P. Y. (1991) Scour Downstream of Grade-Control Structures. Journal of Hydraulic Engineering, 117, 579-594.

D'AGOSTINO, V. \& FERRO, V. (2004) Scour on Alluvial Bed Downstream of Grade-Control Structures. Journal of Hydraulic Engineering, 130, 24-37.

FRITZ, H. \& HAGER, W. (1998) Hydraulics of Embankment Weirs. Journal of Hydraulic Engineering, 124, 963-971.

GAUDIO, R., MARION, A. \& BOVOLIN, V. (2000) Morphological effects of bed sills in degrading rivers. Journal of Hydraulic Research, 38, 89-96.

GUAN, D. (2015) Scour at Submerged Weirs. New Zealnd, University of Auckland.

GUAN, D., MELVILLE, B. \& FRIEDRICH, H. (2014) Flow Patterns and Turbulence Structures in a Scour Hole Downstream of a Submerged Weir. Journal of Hydraulic Engineering, 140, 68-76.

GUAN, D., MELVILLE, B. W. \& FRIEDRICH, H. (2015) Live-Bed Scour at Submerged Weirs. Journal of Hydraulic Engineering, 141, 04014071.

HAGER, W. \& SCHWALT, M. (1994) Broad-Crested Weir. Journal of Irrigation and Drainage Engineering, 120, 1326.

LENZI, M. A., MARION, A. \& COMITI, F. (2003a) Interference processes on scouring at bed sills. Earth Surface Processes \& Landforms, 28, 99-110.

LENZI, M. A., MARION, A. \& COMITI, F. (2003b) Local scouring at grade-control structures in alluvial mountain rivers. Water Resources Research, 39, 1176.

LENZI, M. A., MARION, A., COMITI, F. \& GAUDIO, R. (2002) Local scouring in low and high gradient streams at bed sills. Journal of Hydraulic Research, 40, 731-739.

LU, J.-Y., HONG, J.-H., CHANG, K.-P. \& LU, T.-F. (2012) Evolution of scouring process downstream of grade-control structures under steady and unsteady flows. Hydrological Processes, 27, 2699-2709.

MARION, A., LENZI, M. A. \& COMITI, F. (2004) Effect of sill spacing and sediment size grading on scouring at gradecontrol structures. Earth Surface Processes and Landforms, 29, 983-993.

MARION, A., TREGNAGHI, M. \& TAIT, S. (2006) Sediment supply and local scouring at bed sills in high-gradient streams. Water Resources Research, 42, W06416.
MELVILLE, B. W. (1997) Pier and Abutment Scour: Integrated Approach. Journal of Hydraulic Engineering, 123, 125136.

PAGLIARA, S. \& KURDISTANI, S. M. (2013) Scour downstream of cross-vane structures. Journal of Hydroenvironment Research, 7, 236-242.

SCHMOCKER, L., HALLDÓRSDÓTTIR, B. \& HAGER, W. (2011) Effect of Weir Face Angles on Circular-Crested Weir Flow. Journal of Hydraulic Engineering, 137, 637643.

SCURLOCK, S. M., THORNTON, C. I. \& ABT, S. R. (2011) Equilibrium Scour Downstream of Three-Dimensional Grade-Control Structures. Journal of Hydraulic Engineering, 1, 289.

SHEPPARD, D. M. \& MILLER, W. (2006) Live-Bed Local Pier Scour Experiments. Journal of Hydraulic Engineering, $132,635-642$.

VAN RIJN, L. C. (1984) Sediment transport, part III: bed forms and alluvial roughness. Journal of hydraulic engineering, 110, 1733-1754. 